\title{
SEISMIC DESIGN WITHIN ARCHITECTURAL EDUCATION
}

\author{
A W Charleson'
}

\begin{abstract}
SUMMARY
This paper discusses the teaching of earthquake resistant design within schools of architecture. It aims to stimulate discussion on more effective means of teaching the subject, and to suggest ideas and resources for schools whose seismic design curriculum might benefit from further development.

It is argued that seismic design issues should be included and integrated into architecture curricula. The case is based primarily on observations of building failures resulting from flawed architectural design decisions and subsequent critical reaction from within the architectural profession itself. However, another reason is that the large sizes and restrictive layouts of some seismic load resisting systems impact unavoidably upon architectural layouts.

The content, teaching methods and teaching staff qualities appropriate for a seismic design curriculum are discussed in a case study from the School of Architecture, Victoria University of Wellington. Two key aspects of perceived success are the course's relevance to architectural design and the variety of presentation. Teaching methods, teaching aids and useful references are provided.
\end{abstract}

The evaluation of the courses considered in the case study is discussed, and postgraduate and postgraduation seismic education in New Zealand is reviewed.

\section{INTRODUCTION}

Architects have a large influence on the seismic performance of buildings. Wang [15] has studied building earthquake damage in Algeria, California and Japan, and illustrated the problem of seismically uncritical adherence to prevailing architectural styles. She shows convincingly that this problem has been the most influential factor causing collapses of many reinforced concrete buildings. With reference to two well known damaged Californian buildings she states, "Both the failures of the Imperial County Services Building (El Centro,1979), and the Olive View Hospital (San Fernando, 1971) is unequivocal confirmation of the view that architectural concept may be more detrimental to the seismic survival of a building than any other design decision".

Unfortunately, the history of seismic building damage clearly shows this lesson is generally not taken very seriously. Many factors appear to allow architects to develop architectural concepts that are inherently unsuited to seismic resistance. These may be then accepted by structural engineers, possibly reluctantly, in the belief that the flawed ideas can be improved with sophisticated analysis and design. In the context of poor architectural decisions, and mindful of commercial realities, the engineers do the best they can in the situation.

1 School of Architecture, Victoria University of Wellington (Member)
Often, after a damaging earthquake, the gap between academic knowledge and the correct application of seismic principles in architectural practice becomes painfully apparent. Writing about the structural competence of the architectural profession three years after the disastrous 1985 Mexico City earthquake, Cardenas [6] concludes plaintively that "(as) earthquakes have proved to us, in a very tragic manner", structural input should be provided right throughout an architect's education. This view is also held by architect Christopher Arnold [1]. As he reflects on the same destruction, he argues forcibly that "If we are to prevent new calamities, the profession shall have to amend its practices. From the start of professional training a student must be made conscious of the need to see structure as an integral part of the project and not as some nuisance that the structural designer adds to the architectural project...they must not be viewed as mere add-ons". Later, referring to conversations with Mexican design professionals, he writes: "One of the reactions, both of persons outside the profession and among architects themselves, was to ask for better training in the field of structural design".

Reduction of building and contents damage, personal injury and loss of life in the event of earthquakes is the primary reason for teaching seismic design at an undergraduate level. Seismic design education should not be left to be absorbed during the accumulation of post-graduation experience, nor regarded purely as the province of the engineering profession.

However, there is another reason as well. Frequently the size of structure required to resist seismic loads has a potentially 
greater impact on architectural planning and building configuration than gravity load, or even wind load resisting structure. This is certainly the case for typical low to mediumrise reinforced concrete buildings in Wellington. Experience has shown that seismic load requirements dominate structural footprints; that is to say, the size and shape of structural elements as drawn in plan. The footprint area of seismic load resisting structure is approximately twice that required for wind, and three times that for gravity loads. Significant architectural implications arise since the position of structural walls, crossbracing and columns in plan have the potential to disrupt circulation patterns and severely limit desired areas and patterns of fenestration.

In arguing the importance of teaching seismic design in schools of architecture it has been assumed that a significant seismic hazard exists. This is so for the Pacific rim countries, including New Zealand. However what should be the approach in areas with lesser seismicity? In such cases it would seem reasonable to limit the seismic content of courses but still to ensure students qualitatively understand the basic unique characteristics of seismic loads and design. Internationalisation of architecture has progressed well beyond style. It is becoming more common for buildings in one country to be designed from another.

The challenge is to communicate effectively the importance and content of seismic design to students. Seismic design teaching must be perceived as relevant and related to architectural design studies. It must be integrated with other design issues. To provide a practical framework in which to explore these issues, seismic design education at the School of Architecture, Victoria University of Wellington is reviewed.

\section{DESCRIPTION OF A SEISMIC DESIGN TEACHING PROGRAMME}

The School undergraduate academic programme is based currently upon a two-tier degree structure. After the completion of an intermediate year comprising first year university courses and the first two Professional (Pro) years students can graduate with a BBSc (Bachelor of Building Science). Third and fourth Professional years enable the completion of a BArch (Bachelor of Architecture) degree. Before completing the BArch degree, students are expected to have attained the following levels of structural expertise:-

1. Understand basic structural mechanics in sufficient depth to analyze and design simple statically determinate and indeterminate structural elements. In particular, to quantitatively design timber and steel columns and beams, and reinforced concrete beams in flexure. Qualitative understanding of reinforced concrete shear and column performance is required.

2. Design qualitatively the structural layout of buildings to resist gravity and lateral loads. Structural materials, systems and member sizes are to be appropriate and should satisfy the requirements of other building systems.

3. Appreciate the structural behaviour of soil and its implications for building design and performance, and architectural practice.

4. Understand the importance of building configuration on seismic response and to recognise possible undesirable interaction between structural and non-structural elements.
To conceive suitable damage prevention strategies.

5. To be familiar with the range of less common structural systems such as tension membranes and base-isolation.

6. To be aware of how structural elements can contribute to architectural design quality

Seismic design is a significant component of the Structures courses in the School. Table 1 shows the time allocated first to the Structure's teaching programme that is mandatory, and secondly, to the seismic design component (including wind). It also lists course teaching methods, topics or content and assessment methods. Formal Structures courses occur for the first three professional years only. During the fourth year final design project, structural issues are explored during individual studio tutoring sessions.

An elective structural course for senior students is available. It includes one seismic design project during which students undertake a structural survey of an earthquake risk building and complete the preliminary design of a strengthening scheme.

\section{TEACHING APPROACHES}

At certain periods during the School's history, students have questioned the relevance of much of the Structures courses' content. The two main problems have been first, an unrealistically mathematical and analytical approach, and secondly, that the students have considered the material unrelated to architectural design issues. Black and Duff [3] claim these long-standing problems are still present in many schools of architecture across the United States. In response to these problems, believed to be valid, seismic design teaching at the School is now essentially approached qualitatively. However, students still manipulate several mathematical equations. They calculate the natural period of vibration of a single degree of freedom oscillator, representative of a freestanding water tank or canopy structure; the probability of a random (seismic) event using Poisson's equation, and building seismic base shear by referring to the Loadings Standard [13]. All these calculations develop their understanding of and feel for seismic design issues.

Other quantitative work includes structural analyses of one bay multistorey moment resisting frames. Students are given the locations of points of inflection for beams and columns. The resulting determinate structure can be analyzed and designed readily.

Most building analyses done by students use the concept of 'load paths'. This approach is extremely useful to analyze and describe how seismic loads are transferred into and down primary structural members. Students are not lost in detailed considerations They become familiar with this global approach that forms the basis of the structural analysis and design done at the school during their last two years.

Teaching Structures to architectural students will be most successful if the teachers are enthusiastic about their subject. They must create interest, and just as importantly, show the subject's relevance to architecture. Then they will be contributing to issues fundamental to an architectural perspective of design. 
Table 1 Outline of structural and seismic design curriculum content

\begin{tabular}{|c|c|c|c|c|}
\hline Year of study & 1st Pro year & 2nd Pro year & 3rd Pro year & 4th Pro year \\
\hline $\begin{array}{l}\% \text { of year in } \\
\text { formal } \\
\text { Structures study }\end{array}$ & 17 & 17 & 8 & 0 \\
\hline $\begin{array}{l}\text { Seismic design } \\
\text { component as } \\
\% \text { of Structures } \\
\text { courses }\end{array}$ & 15 & 30 & 30 & 0 \\
\hline $\begin{array}{l}\text { Teaching } \\
\text { method }\end{array}$ & $\begin{array}{l}\text { Lectures and } \\
\text { tutorials }\end{array}$ & Lectures and tutorials & $\begin{array}{l}\text { Lectures, tutorials and } \\
\text { individual tutoring }\end{array}$ & $\begin{array}{l}\text { Individual } \\
\text { tutoring }\end{array}$ \\
\hline $\begin{array}{l}\text { Topics covered } \\
\text { in seismic } \\
\text { design }\end{array}$ & $\begin{array}{l}\text { Concept of } \\
\text { seismic loads } \\
\text { and } \\
\text { introduction } \\
\text { to the } \\
\text { Loading } \\
\text { Standard }\end{array}$ & $\begin{array}{l}\text { Overview of structural dynamics (mainly } \\
\text { qualitative) including; natural period, } \\
\text { damping, resonance, response spectrum, } \\
\text { seismological terminology and definitions, } \\
\text { return period, seismic risk, ductility, } \\
\text { capacity design philosophy, torsion, } \\
\text { vertical and horizontal lateral load } \\
\text { resisting structural systems, and designing } \\
\text { for directionally random shaking. }\end{array}$ & $\begin{array}{l}\text { Seismic load paths, } \\
\text { transfer diaphragms, } \\
\text { elaboration of horizontal } \\
\text { and vertical lateral load } \\
\text { resisting system features, } \\
\text { application of RESIST, } \\
\text { configurational problems } \\
\text { and solutions, non- } \\
\text { structural elements and } \\
\text { base-isolation. }\end{array}$ & \\
\hline Assessment & $\begin{array}{l}\text { Assignments } \\
\text { and exam }\end{array}$ & Assignments, design project and exam & $\begin{array}{l}\text { Assignment, design } \\
\text { project and exam }\end{array}$ & $\begin{array}{l}\text { Design } \\
\text { project } \\
\text { review }\end{array}$ \\
\hline
\end{tabular}

A positive environment for fostering learning and understanding is created where a variety of learning experiences is provided. A wide range of teaching methods is used deliberately in the seismic design sections of the courses. Formal lectures, class tutorial sessions, and individual tutoring or coaching in design studios are the most common. Although these teaching approaches are traditional, they are still considered effective. There is too much background information and conceptua! material to dispense with lectures and rely entirely upon project based teaching.

\section{TEACHING RESOURCES}

Appropriate yet varied resources are used for each aspect taught. They include brief design exercises, a film [14], video clips [4], slides, slide/tape set [5], readings [8], site visits to existing buildings, visiting speakers, model making with drinking straws and sponge rubber, physical demonstrations during lectures, student presentations during which they critically appraise the seismic performance of existing buildings, and finally, the RESIST computer program [7]. Visual material is especially fitting for architecture students. Dramatic case studies illustrating the need of competent seismic design can be presented by showing slides of buildings before and after an earthquake. Model making to investigate alternate vertical lateral load resisting systems has proved a useful "hands-on" learning experience. Short illustrated case studies to develop and reinforce the concept of load paths are frequently presented during lectures.
The computer program RESIST is proving an invaluable resource. It enables students to undertake preliminary designs for lateral loads. Different structural materials, systems and configurations for their design projects are investigated very quickly and easily. Students can compare the seismic adequacy of their designs to the requirements of relevant New Zealand standards. The minimal amount of input, absence of any arithmetic, and user-friendliness make RESIST very attractive to use. Its other advantage is that students can investigate options on their own, thereby reducing staff involvement. This benefit is significant where one staff member is acting as the structural consultant for several classes, each involving fifty. different designs.

No single text alone appears suited to courses on seismic design. Helpful reference material may be obtained from structural texts for architecture students [12] and seismic design publications written specifically for architects [9]. Arnold and Reitherman deal comprehensively with building configuration and seismic performance [2]. This book also incorporates the concept of load paths. Massey [11] provides detailed information on the design of non-structural elements in the New Zealand context.

Two staff members are responsible for the Structure's programme, but for several years one member has been involved half time only.

\section{QUALITIES OF TEACHING STAFF}

The attributes of staff who teach seismic design to architectural students are most important. Ideally, the person most suited to 
the task is an experienced architect with some research background, significant practical seismic design experience, an able communicator and possessing a deep structural understanding. This person's specific strength would be the ability to "speak the same language" as the students; a fellow professional rather than a technical expert or consultant. There would be little risk of the subject being taught at an unnecessarily technical level. However, such a person is hard to find. Witness the very few research publications by architects in the area of seismic design, or their involvement in seismic damage mitigation initiatives. Other options will usually have to be explored.

At the other end of the spectrum, less desirable candidates for teaching seismic design to architectural students are civil engineers. Although technically highly qualified, their research and teaching interests are likely to be oriented towards complex structural analysis. Such people need excellent communication skills to compensate for lacking an understanding and experience of the architect's "world". The all important relationship between seismic and architectural design is likely to be weak, and the students will be less likely to appreciate the subject's relevance.

A satisfactory compromise between these extremes is where an engineer teaching seismic design is encouraged to strengthen the subject's relationship to architectural design; to be committed to bridging the gap between the professions. This strategy, involving the development of research interests immediately relevant to architectural issues, at least in my own experience, has not been easy. It takes several years to begin to engage with a different professional culture.

\section{EFFECTIVENESS OF PROGRAMME}

The effectiveness of a seismic design teaching programme can be partially judged at the conclusion of a course. Student grades are certainly an indication. But what is more important is how the knowledge and concepts are used after graduation. If seismic issues are integrated consciously into a design before initiating discussion with a structural consultant, and when that discussion finally occurs the depth of appreciation of the issues involved becomes apparent, success could be claimed.

Unfortunately this ideal situation occurs too infrequently, even at the School. Often students have gone too far in their project before they address the question of seismic performance. Sometimes, late incorporation of adequate structure is successful, but more often it is not. In these cases structure is tacked on, or forced in. The possibility of the seismic resisting structure becoming a significant architectural element and enriching a design is lost.

The best solution to this problem is the provision of structural tutoring at early stages of student design projects. Unfortunately, due to lack of staff this strategy is often not feasible. Plans to conduct small group tutorials during design projects are currently being explored with architecture design staff. If the mind-set of early consideration of seismic issues can be developed, seismic resistance will not be an afterthought. At the least it will be integrated thoughtfully and satisfactorily into the design, and at best, given its relatively large footprint, it will contribute positively to the architectural concept. Architectural objectives and design quality may be enhanced. However, the difficulties of this approach should not be underestimated. Many other valid architectural concerns await resolution simultaneously and are competing for the designer's attention.

\section{POSTGRADUATE AND POST-GRADUATION PROGRAMME}

Within structural engineering academia there are well established seismic research methodologies and directions. However, the situation within most architecture faculties is different. If the number of referenced theses is an indication, there is virtually no architectural postgraduate study of seismic issues. I am aware of only one $\mathrm{PhD}$ thesis in recent years that addresses an aspect of building seismic response [10] and neither that work, nor other associated literature suggests convincing future research topics and directions. Potential researchers have to trail-blaze.

There is scope for seismic design to be included in continuing professional development programs. Presentations from earthquake damage reconnaissance teams are probably the most popular, particularly if the damaged area possesses cultural and constructional features similar to one's own. Also, there are several developments that warrant increased dissemination to the architectural profession. These include base-isolation and recent developments in national seismic standards and implications for architectural practice. However, New Zealand experience suggests that apart from several enthusiasts, the level of interest in the architectural profession is low. It is unlikely that such seminars or courses will be well subscribed unless they occur shortly after a local damaging earthquake or are presented by an internationally acclaimed designer.

\section{CONCLUSIONS}

It has been argued that seismic design should be present in some form in every school of architecture curriculum. A seismic design teaching programme has been described in some detail, outlining content and teaching methods. Appropriate teaching methodology and personnel are believed to be crucial to a programme's acceptance. However, the primary challenge is for seismic design to become an integral part of architectural design. One promising approach is to supplement seismically focused lecture based course material with increased project based tutoring.

\section{REFERENCES}

1 Arnold, C et al. 1992. Buildings at risk: seismic design basics for practising architects. AIA/ACSA Council on Architectural Research, Washington, DC.

2 Arnold, C and Reitherman, R 1982. Building Configuration \& Seismic Design. John Wiley \& Sons Inc., New York.

3 Black, R G and Duff, S 1994. A model for teaching structures: finite element analysis in architectural education. Journal of Architectural Education 48(1): 38-55.

4 Buckle, I and Fenwick, R 1981. Basic earthquake engineering for structural engineers (a series of three videotapes). The New Zealand Institution of Engineers, Wellington 
5 Building Research Association of New Zealand 1989. Bay of Plenty earthquakes. AV 10 (55 slides), BRANZ, Porirua.

6 Cardenas, J A 1988. The architect's scientific and technological training. In Architectural and Urban design lessons from the 1985 Mexico City earthquake. Council on Architectural Research of the American Institute of Architects and the Association of Collegiate Schools of Architecture, Washington, DC: 105-114.

7 Charleson, A W 1993. Vertical lateral load resisting elements of low to medium-rise buildings, Bulletin of the New Zealand Society for Earthquake Engineering 26(3): 356366.

8 Cooney, R 1982. Strengthening houses against earthquakea handbook of remedial measures. Technical paper P37, Building Research Association of New Zealand, Porirua.

9 Crawley, S W and Ward, D B 1990. Seismic and wind loads in architectural design - an architect's study guide. The American Institute of Architects, Washington, DC.
10 Guevara, L T 1989. Architectural considerations in the design of earthquake-resistant buildings: influence of floorplan shape on the response of medium-rise housing to earthquakes. $\mathrm{PhD}$ thesis, University of California, Berkeley.

11 Massey, W 1992. Architectural Design for Earthquake- a guide to the design of non-structural elements. New Zealand National Society for Earthquake Engineering, Wellington.

12 Schodek, D L 1980. Structures. Prentice-Hall Inc., New Jersey.

13 Standards Association of New Zealand 1992. Code of practice for general structural design and design loadings for buildings. NZS 4203, Wellington.

14 The National Film Library. The Hawkes Bay disaster (1931) (A film). National Film Library, Wellington.

15 Wang, M L 1981. Consequences of architectural style on earthquake resistance. Final proceedings: PRC-US Joint Workshop on Earthquake Disaster Mitigation through Architecture, Urban Planning and Engineering; Beijing, November 2-6 1981: 150-181. 